\title{
Targeting protein-protein interactions using methods of cheminformatics
}

\author{
Art Cherkasov \\ From 7th German Conference on Chemoinformatics: 25 CIC-Workshop \\ Goslar, Germany. 6-8 November 2011
}

We have recently mapped the protein interaction networks of methicillin-resistant Staphylococcus aureus that revealed its scale-free organization with characteristic presence of highly-connected hub proteins that are critical for bacterial survival [1]. Here we report the discovery of highly selective nanomolar inhibitors for one such hub target - staphylococcal pyruvate kinase. The lead compound has been identified through synergetic combination of methods of high-throughput screening and cheminformatics; its further synthetic modifications resulted in much improved antimicrobial properties. Further lead optimization yielded drug candidates with picomolar activity against methicillin-resistant Staphylococcus aureus.

Considering a notable lack of recent reports on novel antibacterial targets and cognate antibacterial compounds, this study provides a valuable perspective on the development of a new generation of antimicrobials. Equally noteworthy, the results of the current work highlight the importance of cheminformatics-driven exploration of chemical space around initial high throughput screening hits.

Published: 1 May 2012

\section{Reference}

1. Cherkasov A, Hsing M, Zoraghi R, Foster LJ, See RH, Stoynov N, Jiang J, Kaur S, Lian T, Jackson L, Gong H, Swayze R, Amandoron E, Hormozdiari F, Dao P, Sahinalp C, Santos-Filho O, Axerio-Cilies P, Byler K, McMaster WR, Brunham RC, Finlay BB, Reiner NE: J Proteome Res 2011, 10:1139-1150.

doi:10.1186/1758-2946-4-S1-P3

Cite this article as: Cherkasov: Targeting protein-protein interactions using methods of cheminformatics. Journal of Cheminformatics 20124 (Suppl 1):P3.

Publish with ChemistryCentral and every scientist can read your work free of charge

"Open access provides opportunities to our colleagues in other parts of the globe, by allowing anyone to view the content free of charge."

W. Jeffery Hurst, The Hershey Company.

- available free of charge to the entire scientific community

- peer reviewed and published immediately upon acceptance

- cited in PubMed and archived on PubMed Central

- yours - you keep the copyright

Submit your manuscript here:

http://www.chemistrycentral.com/manuscript/

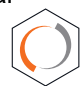

Chemistry Central 